https://doi.org/10.5817/0S2019-2-10

\title{
Сборник статей к 90-летию профессора Адама Евгеньевича Супруна
}

РУДЕНКО, Е. Н., КОЖИНОВА, А. А. (ред.): In honorem: сборник статей к 9о-летию A. Е. Супруна. Минск: Республиканский институт высшей школы, 2018. 280 с. ISBN 978-985-586-151-6.

Кафедра теоретического и славянского языкознания Белорусского государственного университета каждые два года проводит чтения, посвященные памяти основателя кафедры, известного ученого, профессора Адама Евгеньевича Супруна, и издает сборник статей. Этой традиции почти двадцать лет. В настоящий сборник вошли материалы, написанные известными учеными-друзьями и коллегами Адама Евгеньевича, разбросанными по всему миру. В отличие от предыдущих сборников, статьи не ограничены по тематике. Можно сказать, что тематический сборник так же широк, как и творчество профессора Супруна. Материалы в предлагаемом издании представлены на разных языках: русском, белорусском, украинском, польском, чешском, английском.

С жизнью и богатой научной и педагогической деятельностью знакомит читателя во вступлении (Школа Супруна) ${ }^{1}$ сотрудник кафедры теоретического и славянского языкознания, видный представитель современного белорусского языкознания Б. Ю. Норман (Минск).

В каждом сборнике принято публиковать какую-нибудь из работ А. Е. Супруна, мало известную научной общественности. Такая статья (по детской речи) есть и в этом сборнике. Она несет заглавие К особенностям порождающей языковой системы ребенка. ${ }^{2}$ Фонологические проблемы не занимали центрального места в научных интересах А. Е. Супруна. В списке его работ можно найти лишь две короткие публикации, однако отдельные фонологические наблюдения встречаются в других работах. Их содержание разбирает А. В. Андронов (Санкт-Петербург), о которых он говорит, что они являются актуальными и в наши дни (Фонологические заметки о «Фонологических заметках»). ${ }^{3}$ Эквиваленты чешского элатива в русском языке (Protějšky českého elativu v ruštině) ${ }^{4}$ исследует

1 RUDENKO, Je. N., KOŽINOVA, A. A. (red.): In honorem: sbornik statej k go-letiju A. fe. Supruna. Minsk: Respublikanskij institut vysšej školy, 2018, s. 6-8.

2 Там же, с. 9-17.

3 Там же, с. 18-29.

4 Там же, с. 30-39. 
чешский русист A.Brandner (Brno). Как известно, формы сравнительной степени служат прежде всего для выражения предмета сравнения. Однако в чешском языке они могут иметь также значение абсолютного выражения степени качества. Н. А. Валатоўская (Мінск) разбирает отличительные черты восточнославянских языков, а именно в графике, фонетике, орфоэпии, акцентологии, морфологии, синтаксисе, лексикологии (Усходнеславянскія мовы: агульнае і адрознае). ${ }^{5}$ Этимологической проблемой (О спещифике семантического взаимодействия продолжений праславянских глаголов "vezti/*voziti u *vęzti в белорусском и русском языках) ${ }^{6}$ занимается Ж. Ж. Варбот (Москва). Свои наблюдения она сопоставляет с ситуацией в русском и белорусском языках. Проблематику лингвистики текста исследует О. И. Тущева (Минск). В центре ее внимания является попытка проследить, как писательница Светлана Алексеевич конотруирует свои идентичности. Материалом послужили интервью, которые она давала в последние приблизительно 10 лет (Идентичности Светланы Алексеевич). ${ }^{7}$ Языковую политику СССР и Финляндии в Западной Карелии во время Второй мировой войны рассматривает А.В.Зинкевич (Вена): оба государства объявили целью финнизацию территорий; карельский язык трактовался как диалект финского языка (Карелия: финнизация по-советски и по-фински). ${ }^{8}$ К. И. Иванов и Л. П. Супрун-Белевич (Минск) интересуются вопросами перевода. Их внимание привлек болгарский перевод русских сказок, текст которых отличается большим количеством стилистически маркированных языковых единиц (Фольклорный и разговорный орнамент в тексте оригинала и перевода). ${ }^{9}$ B XIV-XVI вв. наблюдается в Европе интерес к астрономии и астрологии. К этому времени относится создание двух славянских манускриптов, написанных на территории Чешского королевства и Великого княжества Литовского. Они содержат сведения астролого-астрономического характера. Н.В. Ивашина (Минск) рассматривает содержащуюся в них астролго-астрономическую терминологию (Астролого-астрономическая терминология в двух средневековых рукописных сборниках). ${ }^{10}$ Состояние современного русского языка, в котором засвидетельствована интервенция заимствований (Всегда ли язык меняется в нужную сторону?) ${ }^{11}$ находится в центре внимания А. М. Калюты (Минск). А. П. Клименко (Минск) пытается

\footnotetext{
5 Там же, с. 40-47.

6 Там же, с. 48-50.

7 Там же, с. 51-62.

8 Там же, с. 63-75.

9 Там же, с. 76-82.

10 Там же, с. 83-94.

11 Там же, с. 95-103.
} 
применить характеристику семантических отношений, выявленных в текстах, к описанию семантических отношений между словами в ассоциативных полях (Типь семантических отношений между стимулом и реакцией в свободно ассоциативном эксперименте). ${ }^{12}$ А. А. Кожинова и Е. С. Суркова (Минск) в своем рассуждении (Ещзе раз об ангеле. К интерпретации некоторых семитизмов в «Книге Даниила из Виленского ветхозаветного свода») ${ }^{13}$ подчеркивают, что варианты интерпретации сакральных терминов-семитизмов свидетельствуют о том, что переводчик стремился корректировать значимые теологические понятия в духе иудиистической экзегезы. Над спецификой функционирования славянских языков в белорусском социокультурном пространстве (Славянские языки в белорусском социокультурном пространстве) ${ }^{14}$ задумывается Л. А. Козловская (Минск). Проблематикой белорусских топонимических названий занимается в своей статье, напечатанной на английском языке (The essence of the onomatological analysis of place names) ${ }^{15}$ А. Корасh (Минск). По словам А. Кречмер (Вена), в тексте «Московские люди XVII века» В.Н. Топорова находится т.наз. микроистория, история частной жизни, возможность ее реконструкции можно осуществить через письменные памятники (Макрои микромир русского человека поздней Московской Руси - на материале частной переписки). ${ }^{16}$ Некоторые этимологические изложения, связанные с названием столицы Беларуси (Некалькі этыммалогій і таямніцы гісторьіі Мінска), ${ }^{17}$ объясняет І. У.Кур'ян (Мінск). Э.Р.Лассан (Вильнюс) подробно разбирает статью А.Е.Супруна «Текстовые реминисценции как языковое явление» (1995), которую считает недостаточно оцененную (Текстовые реминисценции и гражданская лирика - проблемы понимания). ${ }^{18} \mathrm{~K}$ ветхозаветным лингвистическим сюжетам возвращаются О.В. Ламакина (Москва) и В.М. Мокиенко (Санкт-Петербург). В своем очерке они толкуют этимологию фразеологизма «воздать сторицею» (Библейская интерпретация воздать сторицей: вчера и сегодня). ${ }^{19}$ В.А. Маслова (Витебск) вспоминает работы А.Е.Супруна по интерпретации поэтических текстов. Его анализ стихов обнажают проблемы поэтического языка. Этому посвящена ее статья (Поэтическое слово. Памяти

\footnotetext{
12 Там же, с. 104-110.

13 Там же, с. 111-120.

14 Там же, с. 121-128.

15 Там же, с. 129-132.

16 Там же, с. $133^{-145}$.

17 Там же, с. 146-158.

18 Там же, с. 159-168.

19 Там же, с. 169-178.
} 
А.Е. Супруна). ${ }^{20}$ Н.Б. Мечковская (Минск) в своих заметках обращает внимание читателя на то, как в языке соединяется биология и культура (Что в этнических языках обусловлено анатомией и психофизиологией человека и как язык преодолевает биологические гранищы). ${ }^{21}$ Модальность фольклорного текста в аспектах когнитивного изучения (Модальність фольклорного тексту в аспекті когнітивних досліджень) $)^{22}$ разбирается в статье О.О.Микитенко (Київ). Взаимообогащение культур происходит также через перевод языка на язык художественных произведений. Н. Ю. Норман (Минск) полагает, что художественный перевод с русского языка на белорусский позволяет вскрыть и некоторые лингвистические проблемы. Одна из них - это стилистический диапазон языка. Автор показывает на переводе рассказов М. Зощенко, что диапазон стилистических средств белорусского языка оказывается суженным в сравнении с русским (Зощенко - по-белорусску?). ${ }^{23}$ D. Pazio-Wlasłowska (Warszawa) анализирует тематический образ семьи на основании материала, взятого из дневника поэтессы О.Бергольц, созданного в период блокады Ленинграда (Rodzina w leningradzkich dziennikach czasu blokady / na materiale zapisków Olgi Bergholc). ${ }^{24}$ К ранним деловым письменным памятникам восточных славян относятся смоленские грамоты XIII в. В них обнаруживаются самые ранние черты старобелорусского языка, отличные от церковнославянских. Они имеют важное значение для Беларуси и с исторической, и с лингвистической точек зрения. Е. Н. Руденко (Минск) анализирует встречающиеся в смоленских грамотах собственные имена. В своем анализе она ограничивается лишь теми текстами, относящимися к контактам Смоленска с Ригой и Томским берегом, или Готландом (Имена собственные в Смоленско-Рижских грамотах XIII века). ${ }^{25}$ Область лингвистики текста затрагивает статья американского лингвиста G. W. Smitha (Cheney). Автор разбирает употребление собственных имен в произведении В. Шекспира (Names and reference in Shakespeare's Merry Wives of Windsor). ${ }^{26}$ Роль славистики, как филологической специальности, и ее значение для белорусского языкознания описывает М. В. Супрунчук (Мінск). Напоминает, между прочим, заслуги А.Е. Супруна в ее развитии в Беларуси (Некаторыя славістыцныя падыходы у беларусістьщы). ${ }^{27}$ Болгарская лингвистка

20 Там же, с. 179-184.

21 Там же, с. 185-194.

22 Там же, с. 195-206.

23 Там же, с. 207-216.

24 Там же, с. 217-225.

25 Там же, с. 226-242.

26 Там же, с. $243^{-253}$.

27 Там же, с. 254-261. 
Ю.И. Чакырова (Пловдив) посвящает свое исследование некоторым аспектам специфики перевода. Ставит себе цель - проследить, на каком уровне и в какой степени можно сохранить в болгарском языке метафоры оригигала («Картина в картинке» [или перевод концептуальных метафор теории концептуальной метафоры] $)^{28}$

В конце сборника помещено содержание на русском ${ }^{29}$ и на английском языке. $^{30}$

Издание настоящего юбилейного сборника является достойной памятью о жизненном юбилее выдающегося представителя и основателя белорусской славистики нового времени. Его заслугой является то, что с 1993 г. славянские языки и литературы вошли в число основных специальностей на филологическом факультете БГУ. Остается поблагодарить сотрудников кафедры теоретического и славянского языкознания за подготовку присланных материалов в печать.

Алеш Бранднер

\section{Библиография:}

RUDENKO, Je. N., KOŽINOVA, A. A. (red.): In honorem: sbornik statej $k$ go-letiju A. Je. Supruna. Minsk: Respublikanskij institut vysšej školy, 2018.

\section{https://doi.org/10.5817/OS2019-2-11}

\section{Sborník k nedožitým devadesátinám profesora Radoslava Večerky}

MALČÍK, P. (ed.): Vesper Slavicus. Sborník k nedožitým devadesátinám prof. Radoslava Večerky. Praha: Nakladatelství Lidové noviny, 2018. 251 s. ISBN 978-80-7422-620-5.

15. prosince 2017 se uzavřela životní cesta předního českého a evropského slavisty prof. PhDr. Radoslava Večerky, DrSc., Dr.h.c. (mult.). U př́ležitosti jeho

\footnotetext{
28 Там же, с. 262-274.

29 Там же, c. 275-276.

30 Там же, c. 277-278.
} 